\title{
Zastosowanie badań akustycznych w ocenie stopnia nosowania u pacjentów z nosowaniem
}

\section{Assesment of acustic examination in patients with rhinolalia aperta}

\author{
Renata Cudejko ${ }^{1,2,3}$, Wojciech Będziński ${ }^{1,2}$, Adam Piłka ${ }^{1,2}$, Henryk Skarżyński ${ }^{1,2}$ \\ ${ }^{1}$ Instytut Fizjologii i Patologii Słuchu, ul. Zgrupowania AK „Kampinos” 1, 01-943 Warszawa \\ ${ }^{2}$ Światowe Centrum Słuchu, ul. Mokra 17, Kajetany, 05-830 Nadarzyn \\ ${ }^{3}$ Opolskie Centrum Słuchu i Mowy „Medincus”
}

Adres autora: Renata Cudejko, Opolskie Centrum Słuchu i Mowy „Medincus”, ul. Wiejska 122 B, 45-303 Opole; e-mail: r.cudejko@csim.pl

\section{Streszczenie}

Celem pracy było zastosowanie badań akustycznych: sonograficzne SPG i szybkiej transformanty Fouriera FFT w ocenie stopnia nosowania u pacjentów z nosowaniem oraz ustalenie skali nosowania.

Materiał stanowił 46 pacjentów z nosowaniem otwartym z powodu zaburzeń organicznych (rozszczep podniebienia, krótkie podniebienie, niewydolnośc podniebienno gardłowa) oraz grupa kontrolna zdrowych osobników bez cech nosowania. Każdy z pacjentów miał wykonane badania laryngologiczne, ocenę odsłuchową nosowania, wykonaną próbę Czermaka, badanie fiberoskopowe nosogardła, badanie akustyczne w oparciu o MDVP Key system szybką transformantę Fouriera (FFT) i sonograficzne (SPG). W przeprowadzonych badaniach akustycznych najwięcej zmian charakterystycznych dla nosowania zauważono w strukturach harmonicznych podczas mówienia samogłoski „i” w paśmie częstotliwości zakresie od $450 \mathrm{~Hz}$ do 1500 Hz. Stanowi to pasmo o oktawę wyższe od częstotliwości podstawowej dla samogłoski „i”. Na podstawie przeprowadzonych badan akustycznych wyodrębniono obiektywną czterostopniową skalę nosowania otwartego. Badania SPG i FFT są badaniami pomocnymi w obiektywizacji oceny przebiegu rehabilitacji u pacjentów z nosowaniem otwartym.

Słowa kluczowe: nosowanie • badania akustyczne • badania sonograficzne

\section{Abstract}

The aim of this study was to assess the usefulness of acoustic analysis (SPG, FFT) for measuring degree of hypernasality in patients with rhinolalia aperta.

Subjects includes 46 patients with hypernasality due to organic disorders (cleft palate, short palate, velopharyngeal incompetence) and control group. Each patient was subjected to the following assessment: clinical ENT examination with fiberoptic flexible nasopharyngoscopy, perceptual speech assessment and acoustic analysis (FFT, SPG) of vowel "i" using progrm of KAY CSL 4300B.

The results showed that patients with hypernasality had significantly higher energy level for the bands range from $450 \mathrm{~Hz}$ to $1500 \mathrm{~Hz}$ than speakers with normal resonance. The authors showed four-point scale for hypernasality rating. SPG and FFT are good tool to measuring in objective way the progress of rehabilitation in patients with hypernasality and this examination is easy to perform and do not require additional software.

Key words: hypernasality $\bullet$ spectral analysis $\bullet$ spectography

\section{Wstęp}

Nosowanie otwarte jest zaburzeniem rezonansu w mowie, polegającym na tym, że samogłoski i spółgłoski ustne nabierają nosowego brzmienia z powodu braku oddzielenie jamy ustnej od nosowej przy ich powstawaniu [4]. Jest wynikiem dysfunkcji zwieracza podniebienno-gardłowego.

Najczęstszą przyczyną nosowania otwartego są wady rozwojowe twarzoczaszki w postaci rozszczepów podniebienia, 
rozszczepów podśluzówkowych podniebienia, zbyt krótkiego podniebienia, tzw. głębokiego gardła. W warunkach prawidłowych stosunek podniebienia twardego do miękkiego wynosi 2:1. W przypadku niedorozwoju podniebienia wartość ta może wzrastać do 3:1 lub 4:1. Częstość występowania wad rozszczepowych twarzy wynosi 1,6-2/1000 na żywych urodzeń. W Polsce rodzi się z tą wadą około 800 dzieci rocznie [2]. Rozszczep wargi i/lub podniebienia powstaje w skutek nie dokonanego połączenia w linii pośrodkowej między parzystymi wyrostkami twarzowymi i podniebiennymi we wczesnym okresie życia płodowego. Rozległość wady może być różna: od postaci niewielkich rozszczepów do całkowitych. Wg klasyfikacji Kernahana i Starka wyróżnia się dwa typy rozszczepów: pierwotny - obejmuje regiony anatomiczne do przodu od otworu przysiecznego (warga, wyrostek zębodołowy, część podniebienia twardego) oraz wtórny - obejmujący obszar do tyłu od otworu przysiecznego (większa część podniebienia twardego i podniebienie miękkie). Podśluzowkowy rozszczep podniebienia charakteryzuje się triadą objawów: rozdwojenie języczka, brak kolca nosowego tylnego oraz braku zespolenia mięśni podniebienia miękkiego w linii pośrodkowej - przy zachowanej błonie śluzowej [5]. Do prób subiektywnych pozwalających na ocenę rezonansu nosowego należą m.in.: próba Czermaka, próba Gutzmana, próba Seemana. Próby te są łatwe do przeprowadzenia w każdym gabinecie lekarskim, jednak są mało skuteczne w precyzyjnej ocenie nosowania, szczególnie po przeprowadzonych zabiegach rehabilitacyjnych. Dlatego autorzy poszukiwali metody akustycznej, która w sposób obiektywny pozwoli na ocenę obiektywną nosowania.

\section{Cel pracy}

Celem pracy było zastosowanie badań akustycznych sonograficznych (SPG) i szybkiej transformanty Fouriera (FFT) $\mathrm{w}$ ocenie stopnia nosowania u pacjentów z nosowaniem otwartym oraz określenie skali nosowania.

\section{Materiał i metoda}

Materiał obejmował 46 pacjentów z nosowaniem otwartym, w wieku od 6 do 46 lat (średnia wieku 22 lata). Wśród nich było 20 kobiet i 26 mężczyzn. Przyczynami nosowania otwartego w badanej grupie były zaburzenia organiczne takie jak: po operacji rozszczepu podniebienia $(n=19)$, $\mathrm{z}$ krótkim podniebieniem $(\mathrm{n}=10)$, z dysfunkcją pierścienia podniebienno-gardłowego w wyniku rozszczepu podśluzówkowego $(\mathrm{n}=11)$, niewydolności pierścienia podniebienno-gardłowego po adenotomii $(n=6)$ oraz grupa kontrolna $(\mathrm{n}=10)$.

Każdy z pacjentów miał wykonane następujące badania: badanie foniatryczne polegające na ocenie stanu anatomicznego podniebienia, jego ruchomość, stopień zwarcia podniebienno-gardłowego, odległość podniebienia od tylnej ściany gardła, drożność nosa, ocenę odsłuchową nosowania (określenie stopnia nosowania przez lekarza - metoda subiektywna), wykonaną próbę lusterkową Czermaka, badanie fiberoskopowe nosogardła $\mathrm{z}$ oceną zwarcia podniebienno-gardłowego podczas fonacji oraz badanie akustyczne w oparciu o oprogramowanie i interfejs pomiarowy firmy KAY CSL 4300 B. Wśród parametrów akustycznych wybrano szybką transformantę Fouriera (FFT), która jest pomiarem ilościowym i badanie sonograficzne (SPG), które jest pomiarem jakościowym. Sygnał może być opisany w dziedzinie czasowej jako funkcja czasu, albo w dziedzinie częstotliwości jako funkcja częstotliwości. Przejście między tymi dwoma funkcjami można dokonać za pomocą FFT. Pomiary akustyczne przeprowadzono w dźwiękoszczelnym pokoju. Każdy z pacjentów wypowiadał 3-krotnie samogłoskę „i” do mikrofonu umieszczonego $10 \mathrm{~cm}$ od kącika ust. Liczne obserwacje badań akustycznych prowadzone w Instytucie Fizjologii i Patologii Słuchu pozwoliły wykazać, że bardzo pomocną w oznaczaniu stopnia nosowania może być ocena struktury harmonicznej samogłoski „i”. Grupę kontrolną stanowiło 10 osób o prawidłowej emisji głosu dla której wyznaczono normę czyli zerowy stopień nosowania.

W prawidłowym spektrogramie samogłoski „i” widoczne są dobrze zaznaczone (o dużej energii) dwa prążki widma charakterystycznego, z których pierwszy to, częstotliwość podstawowa, drugi to druga harmoniczna. Czasami może być widoczny słabo zaznaczony (o niskiej energii) trzeci prążek - trzecia harmoniczna.

W tym zakresie częstotliwości widmo charakterystyczne wpływa na wyznaczenie pierwszego formantu, który powinien być zawarty pomiędzy 230 a $320 \mathrm{~Hz}$. [Jassem, 1974].

\section{Wyniki}

Częstotliwość podstawowa dla samogłoski „,i” wynosi średnio dla dorosłych i dzieci około $300 \mathrm{~Hz}$. W przeprowadzonych badaniach akustycznych najwięcej zmian charakterystycznych dla nosowania zauważono w strukturach harmonicznych podczas mówienia samogłoski „i” w zakresie od $450 \mathrm{~Hz}$ do $1500 \mathrm{~Hz}$. W paśmie tym zawiera się trzecia, czwarta i piąta składowa harmoniczna. Średnia energia tych składowych decyduje o przesunięciu pierwszego formantu w kierunku wyższych częstotliwości, nawet do $500 \mathrm{~Hz}$. W konsekwencji następuje zmiana barwy fonowanej samogłoski, która brzmi „nosowo”.

FFT przedstawia graficznie amplitudę różnych częstotliwości, pozwala na uwidocznienie amplitudy każdej harmonicznej częstotliwości podstawowej. SPG - spektografia pozwala na pomiary jakościowe poszczególnych formantów.

Na podstawie wykonanych analiz FFT, uśredniono energię trzeciej, czwartej i piątej składowej. Na Rycinie 1 przedstawiono histogram rozkładu natężenia nosowania, wyznaczonego na podstawie uśrednionej wartości trzeciej, czwartej i piątej składowej harmonicznej. Analiza rozkładu wykazała, że wartości układają sie w trzy odrębne grupy. Przyjęto te grupy jako kolejne stopnie nosowania.

Na podstawie analizy rozkładu badań akustycznych wyodrębniono trzy stopnie nosowania:

I stopień - 12-19 dB SPL $(n=16)$,

II stopień - 20-25 dB SPL ( $\mathrm{n}=16)$,

III stopień - powyżej $25 \mathrm{~dB}$ SPL $(\mathrm{n}=14)$.

W Tabeli 1 przedstawiono średnie wartości oraz odchylenie standardowe uśrednionych wartości energii trzeciej, czwartej i piątej składowej harmonicznej dla poszczególnych grup stopnia nosowania oraz wyniki uzyskane w grupie kontrolnej. 


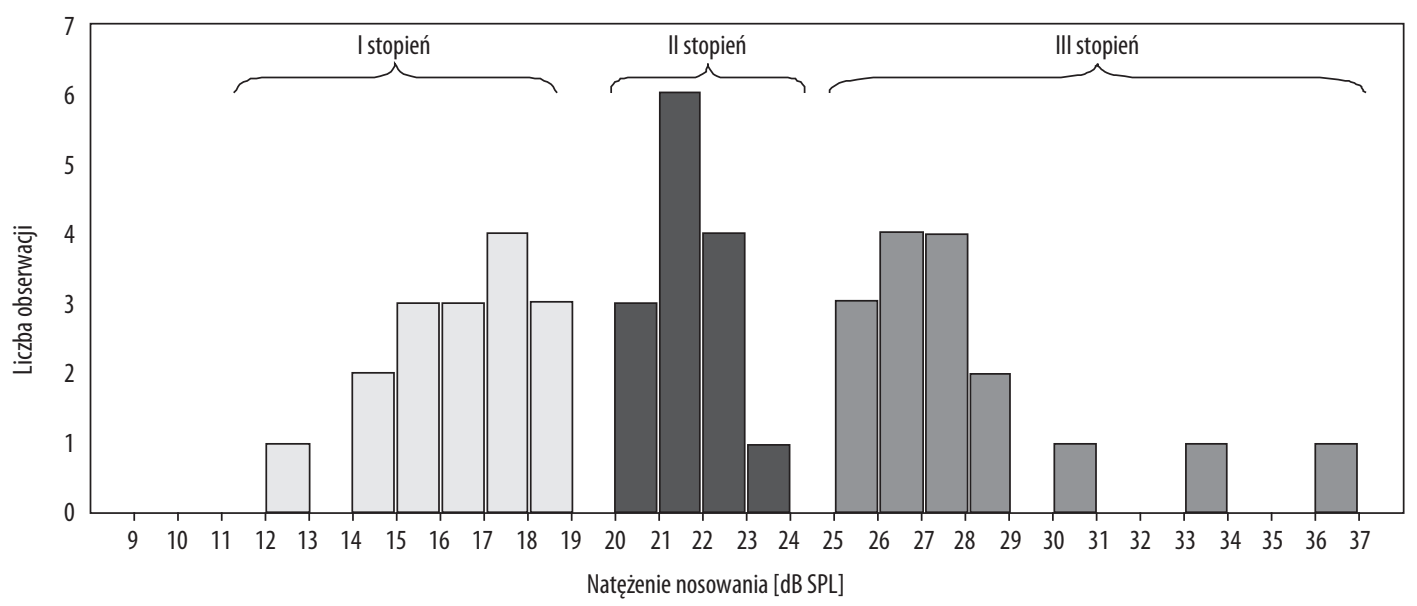

Rycina 1. Histogram rozkładu natężenia nosowania

Tabela 1. Średnie wartości i odchylenie standardowe uzyskane w 4 grupach stopnia nosowania

\begin{tabular}{cccc}
\hline \multirow{2}{*}{ Stopień nosowania } & \multicolumn{3}{c}{ Natężenie nosowania [dB SPL] } \\
\cline { 2 - 4 } & $\mathbf{N}$ & Średnia & SD \\
\hline I & 16 & 16,40 & 2,10 \\
\hline II & 16 & 22,04 & 1,30 \\
\hline III & 14 & 28,35 & 3,39 \\
\hline Grupa kontrolna & 10 & 9,38 & 0,95 \\
\hline
\end{tabular}

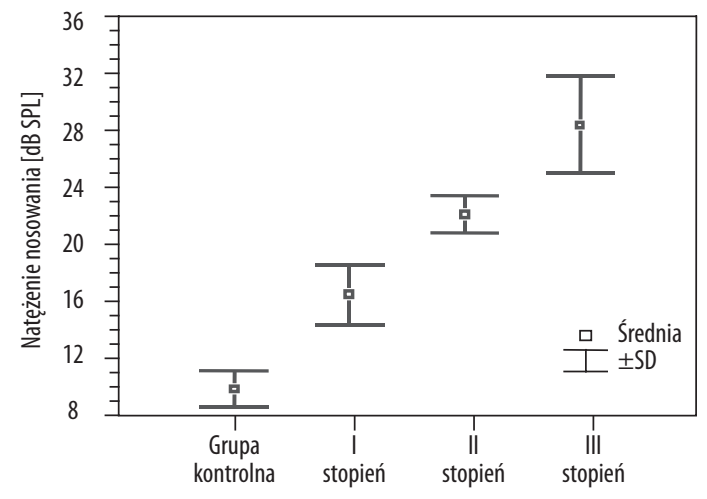

Rycina 2. Wartości średnie oraz odchylenie standardowe natężenia nosowania dla poszczególnych grup nosowania

Analizę statystyczną przeprowadzono w oparciu o test t-studenta dla prób niepowiązanych, porównując wyniki uzyskane dla poszczególnych grup stopnia nosowania w odniesieniu do grupy kontrolnej. Niezależnie od wielkości nosowania uzyskane wyniki są istotnie statystycznie większe niż wyniki uzyskane w grupie kontrolnej. Porównanie wyników uzyskanych dla poszczególnych grup nosowania wykazały, że wartości stopnia nosowania różnią się również między sobą istotnie statystycznie.

Na Rycinie 2 przedstawiono średnie wartości natężenia nosowania w poszczególnych grupach nosowania oraz odchylenia standardowe. Na rysunku umieszczono średnią wartość oraz odchylenie standardowe uzyskane w grupie kontrolnej.

Otrzymane wyniki wskazują, że nosowanie zmienia wartości pomiaru, kwalifikując pacjenta do poszczególnej grupy stopnia nosowania z błędem mniejszym niż $0,01 \%$ oraz, że na podstawie wartości uzyskanych z próby można prawie bezbłędnie zakwalifikować danego pacjenta do danej grupy stopnia nosowania.

U każdej osoby wykonano odsłuchową ocenę stopnia nosowania podczas konsultacji lekarskiej. Na podstawie tej oceny kwalifikowano pacjentów do poszczególnych grup stopnia nosowania. Następnie porównano

wyniki kwalifikacji odsłuchowej z analizami stopnia nosowania wyznaczonego podczas analizy FFT. Szczegóły przedstawiono w Tabeli 2 .

$\mathrm{W}$ analizowanym materiale na podstawie obserwacji odsłuchowych znalazło się 5 osób (10\%) u których lekarz nie stwierdził występowania nosowania. Zdaniem lekarza, aż u 21 osób (ponad 45\%) występował II stopień nosowania. Natomiast analiza wykonana za pomocą FFT wykazała, równomierny rozkład we wszystkich stopniach nosowania. Zwraca uwagę różnice pomiędzy kwalifikacją do poszczególnych grup stopnia nosowania pomiędzy metodą odsłuchową, a akustyczną.Dla głosów o prawidłowej emisji pomiędzy $350 \mathrm{~Hz}$, a $2200 \mathrm{~Hz}$ energia struktury harmonicznej jest zbyt niska, dlatego graficznie nie jest widoczna w analizie spektrograficznej co zostało przedstawione na Rycinie 3. 
Tabela 2. Liczba oraz odsetek badanych zakwalifikowanych po poszczególnych stopni nosowania na podstawie analizy odsłuchowej oraz analizy FFT

\begin{tabular}{ccccc}
\hline \multirow{2}{*}{ Stopień nosowania } & \multicolumn{2}{c}{ Ocena odsłuchowa } & \multicolumn{2}{c}{ Ocena akustyczna } \\
\cline { 2 - 5 } & Liczba & Procent & Liczba & Procent \\
\hline 0 & 5 & $10,9 \%$ & & $0,0 \%$ \\
\hline I & 11 & $23,9 \%$ & 16 & $34,8 \%$ \\
\hline II & 21 & $45,7 \%$ & 16 & $34,8 \%$ \\
\hline III & 9 & $19,6 \%$ & 14 & $30,4 \%$ \\
\hline
\end{tabular}
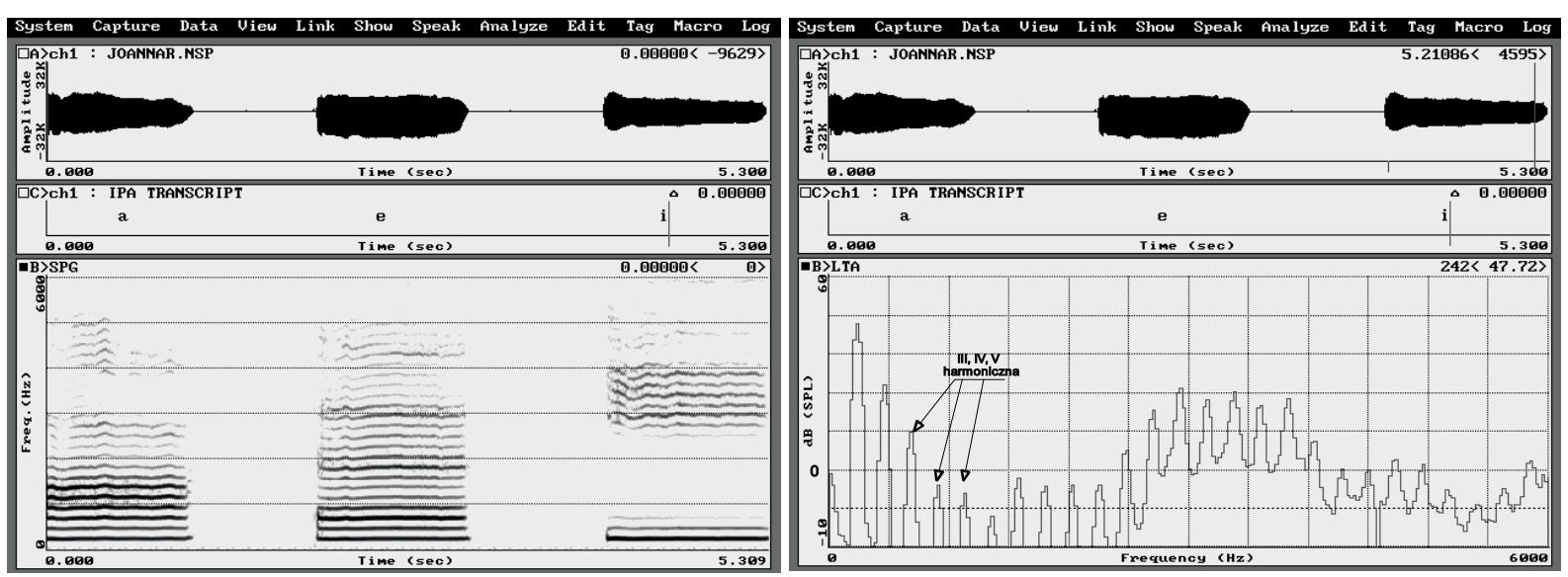

Rycina 3. Spektrogram oraz analiza FFT głosu o prawidłowej emisji. Średnia energia III, IV i V składowej harmonicznej wynosi 9,7 dB SPL
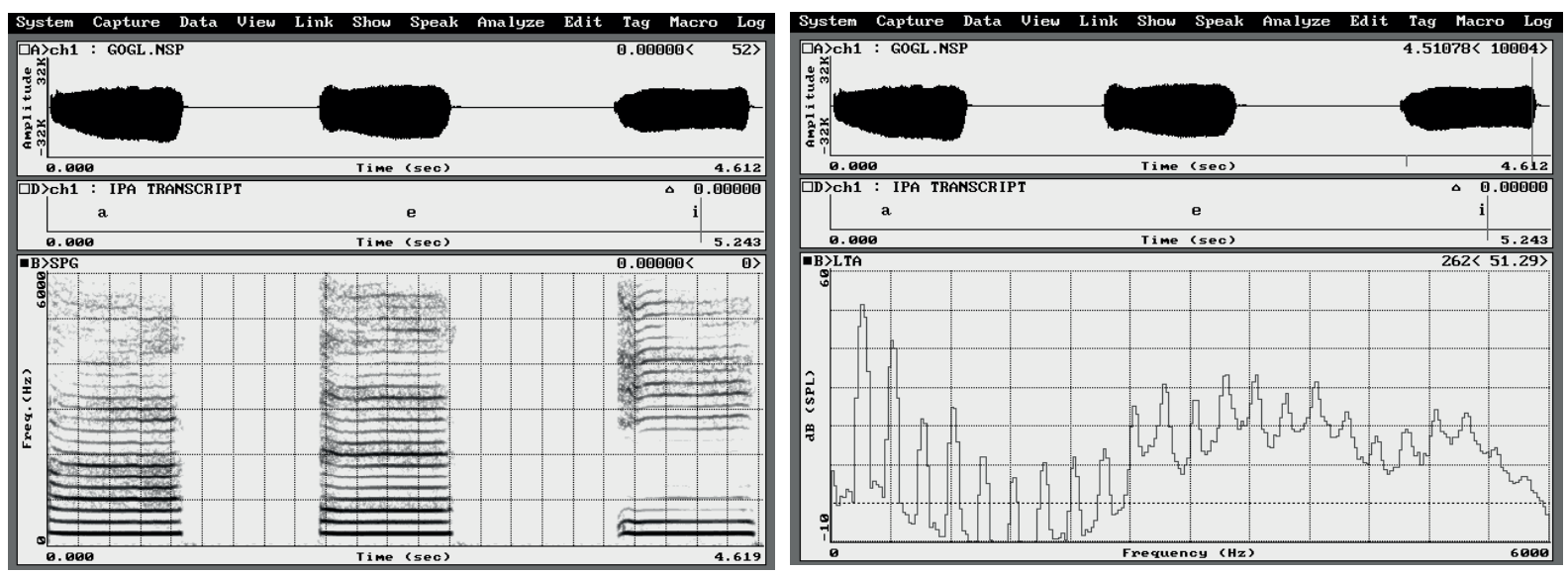

Rycina 4. Spektrogram i analiza FFT przedstawiające I stopień nosowania. W SPG widoczny II stopień chrypki. W analizie FFT średnia energia III, IV i V składowych harmonicznych wynosi $16,5 \mathrm{~dB}$ SPL

Powyżej $2200 \mathrm{~Hz}$ ponownie widać widmo charakterystyczne, które kształtuje drugi i trzeci formant samogłoski „i”. Zawiera się on kolejno pomiędzy: drugi formant (od 2150 do $2400 \mathrm{~Hz}$ ) i trzeci - (od 2750 do $3200 \mathrm{~Hz}$ ).Analiza spektrograficzna, choć daje wiele cennych informacji jest analizą jakościową. Nie można stwierdzić obiektywnie, o ile energia częstotliwości podstawowej w danym badaniu jest większa lub też mniejsza od energii tejże częstotliwości w kolejnych badaniach. Natomiast stosując analizę FFT dla tych samych parametrów pomiarowych tj. częstotliwość odwzorowania, okno ważenia oraz zakres częstotliwości granicznych można obiektywnie ocenić energię kolejnych składowych harmonicznych i pasm formantowych.
Obserwacje wykazały, że dla oceny stopnia nosowania podczas fonacji samogłoski „i” najwięcej charakterystycznych zmian w strukturze harmonicznej występuje w paśmie od 450 do $1500 \mathrm{~Hz}$. Są to częstotliwości o oktawę wyższe od częstotliwości podstawowej dla sam. „i”. W paśmie tym zawiera się trzecia, czwarta i piąta składowa harmoniczna. Średnia energia tych składowych decyduje o przesunięciu pierwszego formantu w kierunku wyższych częstotliwości, nawet do $500 \mathrm{~Hz}$. W konsekwencji następuje zmiana barwy fonowanej samogłoski, która brzmi „nosowo”.Stosując analizę FFT, o której wspomniano wyżej należy uśrednić energię trzeciej, czwartej i piątej składowej. Uśredniona wartość energii bezpośrednio wyznacza stopień nosowania. 

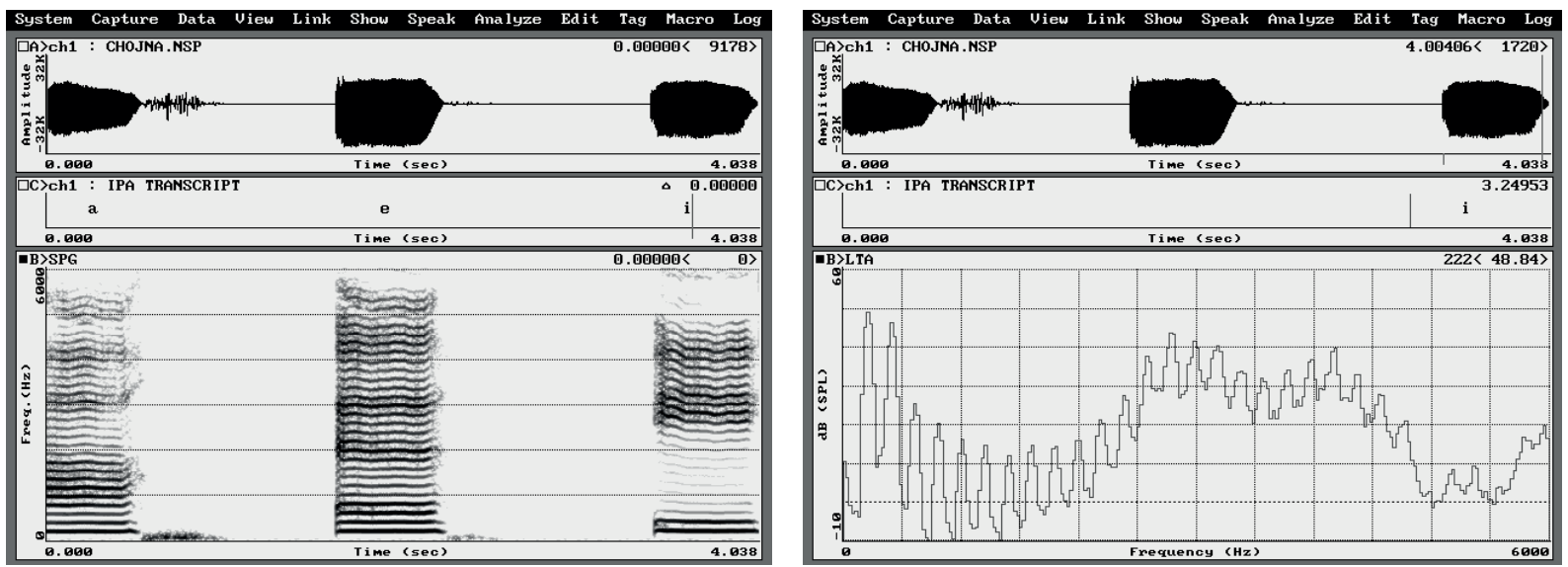

Rycina 5. Spektrogram i analiza FFT przedstawiające II stopień nosowania. W SPG widoczny II stopień chrypki. W analizie FFT średnia energia III, IV i V składowych harmonicznych wynosi 20,4 dB SPL
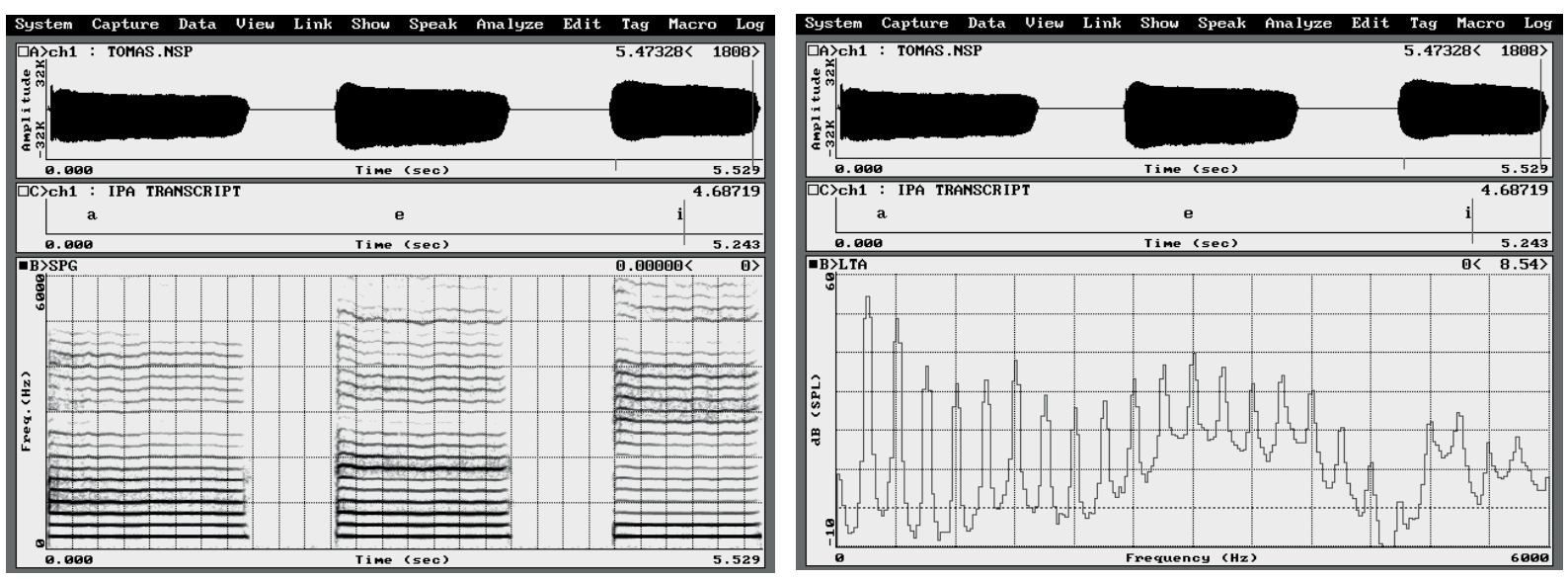

Rycina 6. Spektrogram i analiza FFT przedstawiające III stopień nosowania. W SPG widoczny I stopień chrypki. W analizie FFT średnia energia III, IV i V składowej harmonicznej wynosi 30,5 dB SPL

Na Rycinach 4-6, przedstawiono graficznie przykładowe stopnie nosowania.

\section{Dyskusja}

Stosowanych jest wiele metod określających stopień niewydolności podniebiennej podczas mówienia. Do metod subiektywnych zaliczane są próby: Czermaka, Gutzmana, czy Seemana. Są to metody mało precyzyjne, subiektywne, oparte w dużej mierze na doświadczeniu badającego. Od ponad 20 lat poszukuje się metod, nowych narzędzi do badania funkcji pierścienia podniebienno-gardłowego (VP).

W zależności od warsztatu diagnostycznego stosowane jest wiele metod obiektywnych w celu określenia niewydolności podniebienno gardłowej w mowie. Są to następujące metody: badania radiologiczne: videofluoroskopia, tomografia komputerowa, rezonans magnetyczny, badania endoskopowe nosogardła, badania aerodynamiczne do pomiarów ciśnienia, przepływów, oporów powietrza w jamie nosowej i ustnej podczas mówienia, badania akustyczne, badania elektromiograficzne służące do pomiarów aktywności mięsni podczas mowy [1]. Żadna $\mathrm{z}$ tych metod poza badaniami akustycznymi nie pozwala na ocenę ilościową i jakościową stopnia nosowania. Vallino-Napoli i Montgomery stwierdzili w swoich badaniach, że najlepszym urządzeniem do określenia średniej wartości nosowania jest nasometr. Jest to urządzenie sprzężone $\mathrm{z}$ komputerem dzięki któremu zbiera się sygnał akustyczny z dwóch mikrofonów umieszczonych przed nozdrzami przednimi i przed ustami. Następnie sygnał akustyczny podlega komputerowej obróbce dzięki odpowiedniemu oprogramowaniu. Wynik przedstawia stosunek energii akustycznej zbieranej z górnego mikrofonu do sumy energii zbieranej z górnego i dolnego mikrofonu, dzielony przez 100. Otrzymana liczba przedstawia wartość nosowania [1]. Jednak jak podaje sam producent urządzenia Key Elemetric, wynik $0 \%$ nosowana podczas mowy jest nieosiągalny. Producent tłumaczy to niedoskonałością separacji pomiędzy dwoma mikrofonami. Pojawia się tzw. " przebicie” energii akustycznej pomiędzy oddzielnymi kanałami mikrofonów zbierających sygnał $\mathrm{z}$ ust i nosa. W naszych badaniach akustycznych przeprowadzonych w grupie kontrolnej także nie udało się uzyskać wyniku stopnia zerowego w nosowaniu. Wartości, które uzyskano w tej grupie badanych nie przekroczyły 9,38 dB SPL. Była to grupa zdrowych ochotników i ich otrzymane wartości przyjęliśmy za normę, która posłużyła nam do wyodrębnienia kolejnych stopni nosowania.

Analiza spektrograficzna, choć daje wiele cennych informacji jest analizą jakościową. Nie można stwierdzić obiektywnie 
o ile energia częstotliwości podstawowej w danym badaniu jest większa, lub też mniejsza od energii tejże częstotliwości w kolejnych badaniach. Natomiast stosując analizę FFT dla tych samych parametrów pomiarowych tj. częstotliwość odwzorowania, okno ważenia oraz zakres częstotliwości granicznych można obiektywnie ocenić energię kolejnych składowych harmonicznych i pasm formantowych.

Obserwacje wykazały, że dla oceny stopnia nosowania podczas fonacji sam „i” najwięcej charakterystycznych zmian w strukturze harmonicznej występuje w paśmie od 450 do $1500 \mathrm{~Hz}$. Jeśli emisja głosu jest prawidłowa, średnia energia wymienionych składowych harmonicznych nie przekracza $10 \mathrm{~dB}$ SPL, co zostało zauważone i wyznaczone w naszych badaniach. Wzmożony przepływ powietrza przez tylną ścianę nosogardła powoduje, że w analizie spektrograficznej oraz analizie FFT można zaobserwować pierwszy i drugi stopień chrypy wg. skali Yanagihary w zależności od stopnia zaawansowania nosowania. Uwidacznia się ona jako widmo ciągłe (szum), na którego tle zarysowuje się widmo charakterystyczne. Zaszumienie to wzmacnia się w pasmach formantowych. Z uwagi no to, że energia szumu dodaje się do energii składowych harmonicznych, w analizie SPG samogłoski „i” w paśmie od 450 do $1500 \mathrm{~Hz}$ uwidocznią się składowe harmoniczne o dużej energii. Miejsce, które w prawidłowym spektrogramie było „puste” zapełnione jest prążkami w przypadku obecności nosowania. Stosując analizę FFT, o której wspomniano wyżej należy uśrednić energię trzeciej, czwartej i piątej składowej. Uśredniona wartość energii bezpośrednio wyznacza stopień nosowania. Analiza spektrograficzna, choć daje wiele cennych informacji jest analizą jakościową. Nie można stwierdzić obiektywnie, o ile energia częstotliwości podstawowej w danym badaniu jest większa, lub też mniejsza od energii tejże częstotliwości w kolejnych badaniach. Natomiast stosując analizę FFT dla tych samych parametrów pomiarowych, tj. częstotliwość odwzorowania, okno ważenia oraz zakres częstotliwości granicznych można obiektywnie ocenić energię kolejnych składowych harmonicznych i pasm formantowych.

Badania akustyczne z wykorzystaniem badań spektograficznych (SPG) oraz szybkiej transformanty Fouriera (FFT) okazały się dobrymi badaniami do ustalenia stopnia nosowania oraz stały się badaniami pomocniczymi w ocenie postępów rehabilitacji pacjentów z nosowaniem. Określając stopnie nosowania uzyskaliśmy obiektywne narzędzie do oceny postępów rehabilitacji pacjentów z niewydolnością podniebienno-gardłową (VPI). Jednocześnie dla pacjenta rehabilitowanego pojawił się dodatkowo czynnik psychologiczny w postaci graficznego zapisu FFT i SPG, który w przypadku zmniejszenia nosowania w wyniku rehabilitacji służył pacjentowi jako zachęta do dalszych ćwiczeń. Jak wcześniej wykazano metoda odsłuchowa nie zawsze trafnie służy do oceny stopnia nosowania, dlatego zmniejszenie zapisu nosowania w postaci zmniejszenia amplitudy trzeciej, czwartej i piątej formanty umożliwia wizualizacje osiągnięć rehabilitacji przez pacjenta.

\section{Wnioski}

1. Badania SPG i FFT są badaniami, które pomagają w sposób obiektywny w ocenie stopnia nosowania i są badaniami pomocniczymi w obiektywizacji oceny przebiegu rehabilitacji u pacjentów z nosowaniem otwartym.

2. Na podstawie przeprowadzonych badań akustycznych wyodrębniono obiektywną czterostopniową skalę nosowania otwartego.

3. Stopień nosowania w badaniach akustycznych SPG i FFT dla samogłoski „i” jest niezależny od etiologii, co świadczy o uniwersalności metody.

4. Prezentowane badania akustyczne SPG i FFT są łatwe w przeprowadzeniu i nie wymagają zakupu dodatkowego oprogramowania.

\section{Piśmiennictwo:}

1. Gildersleeve-Neumann Ch.E., Dalston R.M.: Nasalance Scores in Noncleft Individuals: Why Not Zero?. Cleft Palate-Craniofacial Journal, 2001; 38(2): 106-11

2. Hortis M.: Rozszczep wargi i/lub podniebienia - standard postępowania. www.standardy.pl

3. Niedzielska G.: Niewydolność podniebienno-gardłowa. Problemy laryngologiczne w codziennej praktyce. 2005; VI: 3-7

4. Opperbeck J.: Submucous cleft palate as a cause of rhinolalia aperta after tonsillectomy. Z Laryngol Rhinol Otol, 1979; 49(12): 805-8
5. Pruszewicz A.: Nosowanie. (W:) Pruszewicz A (red). Foniatria Kliniczna. PZWL, Warszawa 1972; 196-200

6. Skinder-Meredith A., Cartoski S., Graf N.: A Comparison of nasality measures between Children with Childhood Apraxia of Speech, childen with repaired Cleft palate, and Typically Developing children. Speechpathology, 12/13/2004

7. Vo-Napoli L.D., Montgomery A.A.: Examination of the standard deviation of mean nasalance scores in subjects with cleft palate: Implications for clinical use. Cleft Palate-Craniofacial Journal, 1991; 512-19 